\title{
The Challenges of Virtual Communication in Times of Pandemic in Public Universities in Mexico
}

\author{
Ligia María Bestard Alcántar, Ligia María Río Herrera, Martín Iván Martín Puc \\ Facultad de Contaduria y Administracion. Universidad Autonoma de Yucatan
}

*Corresponding Authors: Ligia María Bestard Alcántar, Facultad de Contaduria y Administracion. Universidad Autonoma de Yucatan, Mexico

\begin{abstract}
This work describes the needs that business professors had to face in the new modality of online classes during the pandemic in order to achieve effective virtual communication in public universities located in Mexico. It is concluded that the use of effective virtual communication in higher education is essential in the new normal and that research should continue to regulate and consolidate it.
\end{abstract}

Keywords: virtual communication, public universities, strategies

\section{INTRODUCTION}

In recent decades, the incorporation into the educational system through computers, computer programs, multimedia, internet, networks, web 3.0 applications, simulators, mobile applications has made teachers adapt to technology and at the same time implement new digital skills, (Gisbert, Esteve and Lázaro, 2019).

However, according to Murillo (2020), the emergence of distance education as a result of the emergency has exposed the existing digital gap between schools and their teachers. Teachers who handle technologies with a pedagogical approach, and know how to design learning processes in virtual environments, are unfortunately the minority. The reality of schools in Latin America is that most of them do not have the necessary skills to take on this tremendous challenge. However, in several cases both education systems and their schools have been faced with the harsh reality of having to become "distance education" schools overnight. Something unthinkable just a few months ago.

Along with this, throughout the region the effects of the confinement are leading to a real situation of social emergency. Millions of people have been left without the minimum income to survive, hunger is increasing as it was not seen decades ago. It is difficult to venture or affirm whether the administrations do not want to, cannot or are not aware of the situation, but what is clear is that in many places it is the society as an organized community, the one that is providing the necessary support. In the face of the disasters of the pandemic, the hope of solidarity and the public as a common good to be cared for and valued emerges with all its force (Murillo, 2020).

For Fernández, Domínguez and Martínez (2020), the phenomenon of the Covid 19 pandemic took practically all social sectors by surprise, nobody was prepared to radically modify daily activities; the education sector was no exception. Going from face-to-face education to distance education, without trained teachers and without sufficient technological infrastructure, was an extremely complicated task. In addition, the students did not know how to behave without the guidance / pressure of their teacher, to which of course, we should add the confusion of parents that had to guide their children so closely in school work.

With the evolution of technology, a form of distance education known as virtual education or elearning arises, where the use of digital and technological resources gives the guidelines for the development of knowledge. Virtual education is a modality that uses digital tools as a first resource and platforms are used to carry out teacher-student interaction. There is an interaction with the class materials and the assignment of tasks within a virtual space (Martínez, 2008). 


\section{LITERATURE REVIEW}

In the context of COVID-19, which is emerging and ever-changing, many countries are being affected by the disease. Also, several universities are closed or about to close physically and are moving towards online and remote learning. For example, New York University in Shanghai and Duke Kunshan University offer examples of successful adaptation and rapid deployment of educational technology products, such as the Zoom video conferencing platform and Moodle. Significantly, these universities had experience with thetechnologies that they were able to expand; they were not starting from scratch with new and unproven technology solutions (Czerniewicz, 2020). Similarly, some schools in Australia have struggled to adapt to the rapid shift to online learning. In the same way, institutions have rapidly innovated and implemented online learning, due in part to an established familiarity with the necessary tools, teaching approaches, and considerations with online learning. This has resulted in fewer interruptions for many students who are unable to return to face-to-face classes (Ali, 2020).

In Mexico, the Federal Government, the Ministry of Health, as well as the Undersecretariat of Prevention and Health Promotion made a declaration of health emergency and established the suspension of non-essential activities from March 30 to April 30, therefore they suspended classes from the basic level to the higher level, both in public and private schools (DOF, 2020). Mexico adopted the strategy of migrating face-to-face courses to virtual ones in an effort to respond to the health emergency guided by the necessary confinement policies. However, the change in educational modality necessarily involves the recognition and management of Information and Communication Technologies as a pedagogical and learning tool (Hernández, 2020).

Higher education relies on different learning strategies, so that the teacher can have a central role in education or the student occupies a central place in their education. In the same way, the contents and resources used in the different learning strategies are based and designed according to who occupies that central role. The Autonomous University of Nuevo León (UANL) and the University of Veracruz (UV) are Higher Education Institutions (IES) that have their own virtual education platform; as Hernández (2020) mentions, it is the institution's own computer archive. Although the use of commercial platforms allows a quick response to the need and demand of using a technological resource (software) to offer a study program in virtual mode, these platforms have limitations in the management and administration of resources and functions (Mariño, 2006).

\section{CONCLUSions}

In public universities in Mexico, teachers had various challenges related to the new online modality in virtual communicationcaused by the Covid-19 pandemic; The skills, knowledge as well as infrastructure and resources were some of the main changes to which they had to adapt or update in order to make virtual communication effective in class sessions with students, however it is uncertain if the students are seizing the opportunities andlearning.

\section{REFERENCES}

Ali, W. (2020). Online and Remote Learning in Higher Education Institutes: a Necessity in Light of COVID-19 Pandemic. Higher Education Studies. 10 (3), 16-26.

Czerniewicz, L. (2020). What We Learnt from "Going Online" during University Shutdowns in Sudafrica.Obtenido de: https://philonedtech.com/what-we-learnt-from-going-online-during-universityshutdowns-in-south-africa/

Diario Oficial de la Federación. (DOF, 2020). Acuerdo por el que el Consejo de Salubridad General reconoce la epidemia por el virus SARSCoV2 (COVID-19) en México, como una enfermedad grave de atención prioritaria, así como se establecen las actividades de preparación y respuesta ante dicha epidemia $\quad$. 23 Marzo 2020. Obtenido de: https://www.dof.gob.mx

Fernández, J., Domínguez, J.,y Martínez, P. (2020). De la Educación Presencial a la Educación a Distancia en Época de Pandemia por Covid-19. Experiencias de los Docentes. Revista Electrónica sobre Cuerpos Académicos y Grupos de Investigación. 7(14), 1-24.

Gisbert, M., Esteve, V., y Lázaro, J. (2019). ¿Cómo Abordar la Educación del Futuro? Conceptualización, Desarrollo y Evaluación desde la Competencia Digital Docente. Guatemala. Editorial Octaedro.

Hernández, A. (2020). Educación Virtual en México: Desafío Emergente COVID-19. Revista Dilemas Contemporáneos: Educación, Política y Valores. 62(1), 1-14. 
Hernandez, S. R. (2014). Metodología de la Investigación. México D.F.: Mc Graw Hill.

Mariño, J. (2006). B-Learning Utilizando Software Libre, una Alternativa Viable en Educación Superior. Revista Complutense de Educación. 17, 121-133.

Martínez, C. (2008). La Educación a Distancia, sus Características y sus Necesidades en la Educación Actual. Educación. 17(33), 7-27.

Martinez-Migueles, M. (2004). Ciencia y arte de la metodología cualitativa.México, D.F.: Trillas.

Murillo, F. (2020). El Covid-19 y las Brechas Educativas. Revista Latinoamericana de Educación Inclusiva. 14(1), 11-13.

Taylor, S., \& Bodgan, R. (1987). Introducción a los métodos cualitativos de investigación. Buenos Aires: Ediciones Paidos Ibérica S. A.

\section{AUTHORS' BIOGRAPHY}

Ligia María Bestard Alcántar, Full time professor in the Facultad de Contaduría y Administración, UADY, Tizimin Mulitidisciplinary Unit. M.Ed, UNID. B.S. in Public Accounting: Universidad Autónoma de Yucatán (UADY).

Ligia María Río Herrera, Full time professor in the Facultad de Contaduría y Administración (FCA, UADY). M. Ed in Innovation, Universidad Autónoma de Yucatán (UADY). B.S. in Public Accounting, Universidad Autónoma de Yucatán (UADY).

Martin Ivan Martin Puc, is full time professor in the Facultad de Contaduría y Administración, UADY. Independent Consultant $\mathrm{PhD}$ in Taxation Sciences, Instituto de Especialización para Ejecutivos. M.S. in Taxation, Instituto de Especialización para Ejecutivos. B.S. in Public Accounting, Universidad Autónoma de Yucatán (UADY).

Citation: Ligia María Bestard Alcántar, et.al, The Challenges of Virtual Communication in Times of Pandemic in Public Universities in Mexico" International Journal of Managerial Studies and Research (IJMSR), vol 9, no. 9, 2021, pp. 29-31. doi: https://doi.org/10.20431/2349-0349.0909004.

Copyright: (C) 2021 Authors. This is an open-access article distributed under the terms of the Creative Commons Attribution License, which permits unrestricted use, distribution, and reproduction in any medium, provided the original author and source are credited. 